\title{
Analisis Faktor Eksternal Dan Internal Terhadap Pembiayaan Pada Bank Umum Syariah Yang Terdaftar Di OJK
}

\author{
Annisa Nadya \\ Universitas Pembangunan Nasional Veteran Jakarta \\ anisanadya81@gmail.com

\section{Marlina Tanjung} \\ Universitas Pembangunan Nasional Veteran Jakarta \\ marlinatanjung0903@gmail.com \\ Sugianto \\ Universitas Pembangunan Nasional Veteran Jakarta \\ sugiantosemm@gmail.com
}

Received: October 2, 2020 | Accepted: November 22, 2020 | Published: November 25, 2020

\begin{abstract}
This research is a quantitative study to determine the effect of inflation, BI interest rates, capital influences and problematic financing on financing at Islamic banks. The dependent variable in this study is financing. While the independent variables in this study are inflation, Bl interest rates, capital, and problem financing. The population of this study is Sharia Commercial Banks registered with the Financial Services Authority, which amounts to 14 Banks. The sample selection uses non probability sampling. The data used are secondary data with panel data analysis method using e-views 10 . The sample used was 14 Sharia Bank for the period of 2016-2018. The results of panel data regression with a significance level of 0.05 indicate that inflation, $B$ I interest rates, and problematic financing have no effect on financing, and capital influences has effect on financing.
\end{abstract}

Keyword: Inflation; BI Interest Rates; Capital Influences; Financing

\begin{abstract}
Abstrak
Penelitian ini merupakan penelitian kuantitatif untuk mengetahui pengaruh Inflasi, kebijakan suku bunga Bank Indonesia, modal pada bank dan pembiayaan bermasalah terhadap Pembiayaan pada bank umum syariah. Variabel dependen dalam penelitian ini adalah jumlah pembiayaan. Variabel independen dalam penelitian ini adalah inflasi, suku bunga Bank Indonesia, permodalan, dan pembiayaan bermasalah. Populasi dalam penelitian ini yaitu Bank Umum Syariah yang terdaftar di Otoritas Jasa Keuangan yang berjumlah 14 Bank. Pemilihan sampel menggunakan non probability sampling. Data yang digunakan dalam penelitian ini adalah data sekunder dengan metode analisis regresi data panel dengan menggunakan aplikasi E-views 10. Sampel yang digunakan sebanyak 42 Bank Umum Syariah periode tahun 2016-2018. Hasil dari regresi data panel dengan tingkat signifikansi sebesar 0.05 menunjukkan bahwa Inflasi, suku bunga $\mathrm{BI}$, dan pembiayaan bermasalah tidak terdapat pengaruh terhadap pembiayaan, dan permodalan berpengaruh terhadap pembiayaan.
\end{abstract}

Kata kunci: Inflasi, Suku Bunga BI, Permodalan, Pembiayaan Bermasalah dan Pembiayaan. 


\section{PENDAHULUAN}

Perekonomian di Indonesia memiliki persaingan dunia bisnis yang beragam. Salah satu sektor yang paling pesat kemajuannya dalam persaingan ekonomi adalah perbankan. Perbankan merupakan suatu badan, lembaga usaha atau sebagai lembaga intermediasi yang menghimpun dan memberikan dananya kembali dalam bentuk pinjaman dana kepada masyarakat dimana pembiayaan atau pinjaman dana ini menjadi salah satu sumber pendapatan daripada bank. Perbankan syariah merupakan sektor yang mampu melewati dan berdiri kokoh pada saat terjadi krisis ekonomi pada tahun 1998 dan 2008 khususnya bank syariah. Karena bank syariah yang tidak mengimplementasikan sistem bunga namun menerapkan sistem bagi hasil dengan profit sharing, yakni membagi net income atau keuntungan bersih dari hasil usaha atau investasi yang dijalankan. Menurut Dyatama dan Yuliadi (2015) hal ini dapat dilihat bahwa kinerja bank syariah sangat baik dan meskipun tidak menerima bantuan dana dari pemerintah masih dapat bertahan. Perbankan syariah tetap dalam kondisi baik dan memberikan keuntungan, keamanan dan kenyamanan kepada pemegang sahamnya, penyimpanan dana di bank, pinjaman, serta surat berharga.

Upaya dalam menjalankan tugas bank dengan menyalurkan pembiayaan agar terlaksana dengan baik, maka tidak terlepas dari faktor-faktor yang dapat mempengaruhi besaran jumlah pembiayaan tersebut. Faktor tersebut diantaranya faktor eksternal dan faktor internal bank. Faktor eksternal merupakan faktor yang bersifat makro atau berasal dari luar perusahaan dimana faktor tersebut tidak dapat dikendalikan oleh perusahaan. Sedangkan faktor internal adalah faktor yang berada dari dalam perusahaan dimana faktor ini masih dapat dikendalikan oleh perusahaan ini sendiri. Seperti salah satunya permasalahan kinerja keuangan bank yaitu permodalan bank dan pembiayaan bermasalah.

Salah satu faktor eksternal yang sangat mengganggu pertumbuhan ekonomi Indonesia adalah laju inflasi. Apabila terjadi kenaikan laju inflasi, pemerintah Indonesia akan merespon dengan mengeluarkan kebijakan moneter yaitu menaikkan suku bunga. Sehingga bank konvensional dapat memanfaatkan keadaan tersebut untuk memperoleh pendapatan yang tinggi. Namun keadaan ini berbeda dengan bank syariah. Bank syariah merupakan bank yang operasionalnya tidak mengenal sistem bunga dan bukan sebagai pendapatan, sehingga bank syariah sulit mendapatkan likuiditasnya.

Dalam tingginya jumlah pembiayaan, maka risiko kerugian yang akan terjadi dapat meningkat juga yang akan mempengaruhi kinerja keuangan atau faktor internal perusahaan. Faktor internalnya diantaranya yaitu akan diikuti oleh meningkatnya pembiayaan bermasalah dan akan mempengaruhi jumlah modal. Jika pembiayaan dalam bank syariah menggunakan akad bagi hasil yaitu apabila debitor mengalami kerugian maka kerugian tersebut akan dibebani oleh bank syariah itu 
sendiri. Sehingga perbankan akan menutupi hal tersebut dengan meningkatkan jumlah modal sebagai aktiva tertimbang menurut risiko (ATMR).

Kondisi perekonomian lainnya di Indonesia yang menjadi perhatian adalah laju inflasi. Ketika terjadi kenaikan inflasi maka bank akan menaikkan kebijakan suku bunga pinjaman untuk meminimalisir sejumlah uang yang beredar sehingga nasabah yang mengajukan pembiayaan kepada bank akan berkurang karena meningkatnya bunga pinjaman, hal ini dapat mempengaruhi jumlah pembiayaan yang disalurkan oleh bank (Akbar dan Munawaroh 2014).

Bank dalam memberikan pembiayaan harus berdasarkan ketentuan dari suku bunga acuan. Pembiayaan ini akan dipengaruhi oleh suku bunga Bank Indonesia atau berdasarkan sumber dana pihak ketiga dalam pemberian pembiayaan. Suku bunga bank atau yang dinamakan sebagai BI 7day Repo Rate adalah kebijakan baru yang dilakukan oleh Bank sentral Indonesia untuk penguatan operasi moneter yang berlaku sejak tanggal 19 Agustus 2016 yang menggantikan suku bunga Bank Indonesia yaitu BI Rate.. Menurut Kasmir 2014, hlm. 116) apabila suatu bank menetapkan target laba yang cukup besar maka bunga kredit juga akan menjadi tinggi, begitu juga sebaliknya. Dengan kata lain, suku bunga ini akan mempengaruhi jumlah pembiayaan yang disalurkan oleh suatu bank.

Dalam melakukan tugas perbankan dengan menyalurkan pembiayaan, bank memerlukan ketersediaan modal yang cukup. Kecukupan modal yang utama merupakan dana dari pihak ke satu dan modal tersebut dapat mengukur kemungkinan resiko yang dapat terjadi. Semakin meningkatnya ketersediaan modal maka semakin besar juga sumber dana finansial yang bisa dimanfaatkan untuk kegiatan operasional perusahaan dan menanggulangi potensi kerugian yang diakibatkan oleh penyaluran pembiayaan menurut penelitian Wardiantika dan Kusumaningtias (2014).

Kualitas kesehatan bank dapat dilihat salah satunya seberapa tinggi kredit bermasalah bank. Dalam konteks perbankan syariah dinamakan pembiayaan bermasalah. Dalam hal ini, bank akan menangani pembiayaan bermasalah dengan prinsip kehati-hatian, dan dapat menurunkan jumlah pembiayaannya. Menurut (Bakti 2018), semakin meningkat pembiayaan bermasalah, maka jumlah pembiayaan akan semakin menurun yang disebabkan karena ketika pembiayaan bermasalah yang meningkat maka perbankan syariah berhati-hati memberikan pembiayaan kepada nasabah untuk meminimalkan pembiayaan bermasalah. Berdasarkan penjelasan dilatar belakang, diperoleh rumusan masalah yaitu apakah terdapat pengaruh inflasi, suku bunga $\mathrm{BI}$, permodalan dan pembiayaan bermasalah terhadap pembiayaan.

Penelitian bertujuan untuk mengetahui pengaruh inflasi, suku bunga $\mathrm{BI}$, permodalan dan pembiayaan bermasalah terhadap pembiayaan secara parsial. Secara teoritis, penelitian ini bermanfaat untuk menambah ilmu pengetahuan 
tentang faktor makro dan faktor mikro terhadap pembiayaan pada perbankan syariah dan dapat digunakan sebagai untuk penelitian selanjutnya. Dan secara praktisnya penelitian ini diharapkan dapat dimanfaatkan sebagai bahan pertimbangan dalam pemberian pembiayaan atau dana dari bank kepada nasabah dengan memperhatikan faktor eksternal seperti inflasi dan perbankan serta faktor internal tentang kecukupan modal dan pembiayaan macet.

\section{TINJAUAN PUSTAKA}

\section{Teori Asimetri Informasi, Teori Sinyal, dan Pembiayaan}

Teori Asimetri Informasi ialah kondisi jika pemilik perusahaan atau atasan perusahaan tidak memiliki informasi yang cukup tentang kinerja bawahan terhadap hasil yang sebenarnya. Menurut Hasibuan (2015), persoalan asimetri informasi terletak pada manfaat, tujuan, dan sasaran pembiayaan yang tepat dan dapat tercapai jika bank mendapatkan informasi sejak awal tentang usaha bisnis debitur dan kreditur. Dengan tanpa mendapatkan informasi yang cukup fair, bank akan kewalahan untuk membangun perjanjian kontrak yang adil, yang dapat memenuhi manfaat, tujuan, dan target sasaran pembiayaan tersebut.

Teori sinyal atau persinyalan merupakan dampak dari adanya informasi asimetri. Menurut Suryani dan Hendryadi $(2015, \mathrm{hlm}$. 30) mengemukakan tentang singnalling theory bahwa bagaimana seharusnya dalam perusahaan memberikan sinyal kepada masyarakat yang membutuhkan laporan keuangan sebagai pertimbangan dalam membuat keputusan. Sinyal yang diberikan dari perusahaan ini dapat mencerminkan kinerja perusahaan dalam aspek keuangan maupun nonkeuangan dan pencapaian perusahaan yang telah dinilai baik yang belum diraih dalam mengimplementasikan harapan dan keputusan pihak eksternal perusahaan seperti nasabah atau pemegang saham. Dari informasi yang didapat, dapat memberikan sinyal tingkat kesehatan perusahaan. Penilaian tingkat kesehatan perusahaan merupakan hasil akhir dari aspek dalam hal kontrol dan pengawasan perbankan yang menunjukkan kinerja perbankan secara Nasional. Dalam hal ini teori sinyal sangat penting sebelum dilakukannya pembiayaan. Apabila perusahaan memberikan sinyal yang baik kepada masyarakat, atau sebaliknya, maka masyarakat akan tertarik dalam melakukan pinjaman dana.

Menurut Muhammmad Ridwan (2018) pengertian pembiayaan secara luas adalah "financing atau pembelanjaan, yaitu dana yang dikeluarkan oleh pihak tertentu untuk mendorong aktivitas pendanaan yang telah dipersiapkan baik dilakukan oleh seorang diri maupun bersama-sama. Secara sempit, pembiayaan didefinisikan sebagai investasi yang dilakukan oleh lembaga pembiayaan seperti perbankan syariah kepada nasabah. Tugas ini diatur dalam UU Perbankan Syariah No. 
21 tahun 2008. Pembiayaan inilah merupakan pemberian fasilitas dana berupa tagihan yang diberikan oleh bank kepada nasabah yang mengalami defisit atau kekurangan dana dengan ketentuan-ketentuan untuk mengembalikan dana tersebut dalam kurun waktu tertentu dengan profit sharing.

\section{Inflasi dan Pembiayaan}

Menurut Machfudz dan Sujoni (2016, hlm. 72), inflasi merupakan kondisi atau gejala dimana meningkatnya biaya dan harga, yaitu meningkatnya harga-harga sandang pangan dan papan. Dapat juga dikatakan kenaikan barang-barang secara umum dan faktor-faktor produksi. Menurut Lin, Farhani, dan Koo, (2016) kondisi faktor ekonomi merupakan sumber utama risiko sistematis yang menggambarkan pertumbuhan dan penurunan pinjaman. Selama penurunan harga aset yang disimpan sebagai jaminan akan menurun juga dan dapat menumbuhkan pertumbuhan pembiayaan. Dalam hal ini sangat penting bagi pemerintah untuk mengidentifikasi faktor-faktor ekonomi. Menurut Salma Fathiya Ma'arifa (2015) dan Waemustafa dan Sukri (2015) inflasi berpengaruh terhadap kegiatan transaksi pada lembaga keuangan khususnya perbankan. Dari perubahan inflasi akan mempengaruhi biaya dan pendapatan secara riil. Adanya kenaikan inflasi akan direspons oleh kebijakan pemerintah yaitu dengan mengeluarkan kebijakan moneter dengan menaikkan $\mathrm{BI} 7$ day Repo Rate yang akan mengakibatkan peningkatan suku bunga $\mathrm{BI}$ dan akan diikuti oleh peningkatan pula suku bunga pinjaman bank.

\section{Suku Bunga BI dan Pembiayaan}

Dalam rangka penguatan operasi moneter, Bank Indonesia melakukan kebijakan dengan mengimplementasikan kebijakan suku bunga. Secara umum suku bunga adalah sejumlah harga yang harus dilunasi kepada nasabah yang memiliki simpanan dan yang harus dilunasi kepada nasabah yang memperoleh pinjaman yang jumlah ditentukan oleh permintaan dan penawaran akan dana yang ditawarkan di pasar. Menurut Bank Indonesia (2018), SBBI adalah kebijakan suku bunga dari implementasi kebijakan moneter yang ditetapkan oleh bank sentral Indonesia yang diberikan kepada masyarakat secara transparansi. Menurut Wicaksono (2015) dan Riyadi dan Raffii 2018, suku bunga Bank Indonesia memiliki pengaruh terhadap pembiayaan. Dengan semakin tingginya tingkat suku bunga, akan diikuti dengan meningkatnya suku bunga yang ada di perbankan, baik suku bunga pinjaman maupun suku bunga simpanan. Hal ini akan mempengaruhi jumlah profit sharing pada suatu bank syariah karena besarnya jumlash hasil profit sharing pada bank syariah akan bersaing dengan suku bunga pada bank konvensional. Dengan pinjaman yang tinggi, dengan tingkat suku bunga yang tinggi, akan menghasilkan profit yang tinggi pula akan tetapi minat nasabah dalam melakukan pinjaman akan cenderung menurun. 


\section{Permodalan dan Pembiayaan}

Vijaya dan Irwansyah (2018) modal merupakan peran aktiva sebagai penunjang keuntungan usaha yang harus secara simultan diikuti dengan pertumbuhan pertimbangan risiko yang mungkin terjadi guna melindungi kepentingan pemegang saham. Jika bank tersebut berpotensi, maka modal dapat dikatakan salah satu faktor yang penting dalam pertumbuhan perusahaan dan dapat mengatasi risiko kerugian.

Kecukupan modal merupakan salah satu faktor penting dalam menjalan kegiatan usaha. Dengan ketersediaan modal yang cukup, maka bank akan semakin baik dalam menghadapi resiko kerugian yang bisa saja terjadi. Risiko kerugian yang dapat timbul dapat terjadi apabila selama menjalankan tugas bank dengan menyalurkan pembiayaan atau dana terdapat klasifikasi pembiayaan macet atau bermasalah, maka modal yang akan menutupi kemungkinan kerugian. Semakin tinggi modal juga akan mempengaruhi kepercayaan diri bank dalam melakukan pembiayaan dalam jumlah yang besar. sendiri. Oleh karena itu untuk mengatasi kemungkinan risiko yang akan dihadapi bank harus menyediakan minimum ketersediaan modal (Ryad, 2017) dan Syaikh, dan Siddik (2017)

\section{Pembiayaan Bermasalah dan Pembiayaan}

Menurut Ramadhan (2017) pembiayaan bermasalah merupakan pembiayaan yang kualitasnya berdasarkan atas risiko kemungkinan yang terjadi terhadap kondisi dan ketaatan nasabah pembiayaan dalam menyelesaikan kewajibannya untuk membayar bagi hasil. Pada sistem perbankan konvensional dikenal dengan istilah kredit bermasalah atau Non Performing Loan, juga dikenal dalam sistem perbankan syariah dengan istilah pembiayaan macet atau Non Performing Finance (NPF). Apabila suatu bank dengan tingkat NPF rendah, maka masyarakat akan lebih percaya dengan bank tersebut dibandingkan dengan bank yang memiliki tingkat NPF yang tinggi. Dalam rangka untuk menjaga tingkat kepercayaan inilah NPF sangat perlu diatasi (Maidalena 2014).

\section{Metode Penelitian Empirik}

Dalam penelitian ini, terdapat empat variabel independen yang memengaruhi variabel dependen. Variabel tersebut adalah inflasi, suku bunga Bank Indonesia atau BI 7day Repo Rate, rasio kecukupan modal atau CAR (Capital Adequacy Ratio), dan rasio pembiayaan bermasalah atau NPF (Non Performing Fincance) terhadap jumlah pembiayaan yang disalurkan oleh bank umum syariah. Berdasarkan latar belakang dan tujuan penelitian yang sudah dijelaskan, maka dapat digambarkan untuk menyusun kerangka pikir penelitian yang dapat dilihat pada gambar berikut: 


\section{Gambar 1. Kerangka Pemikiran}

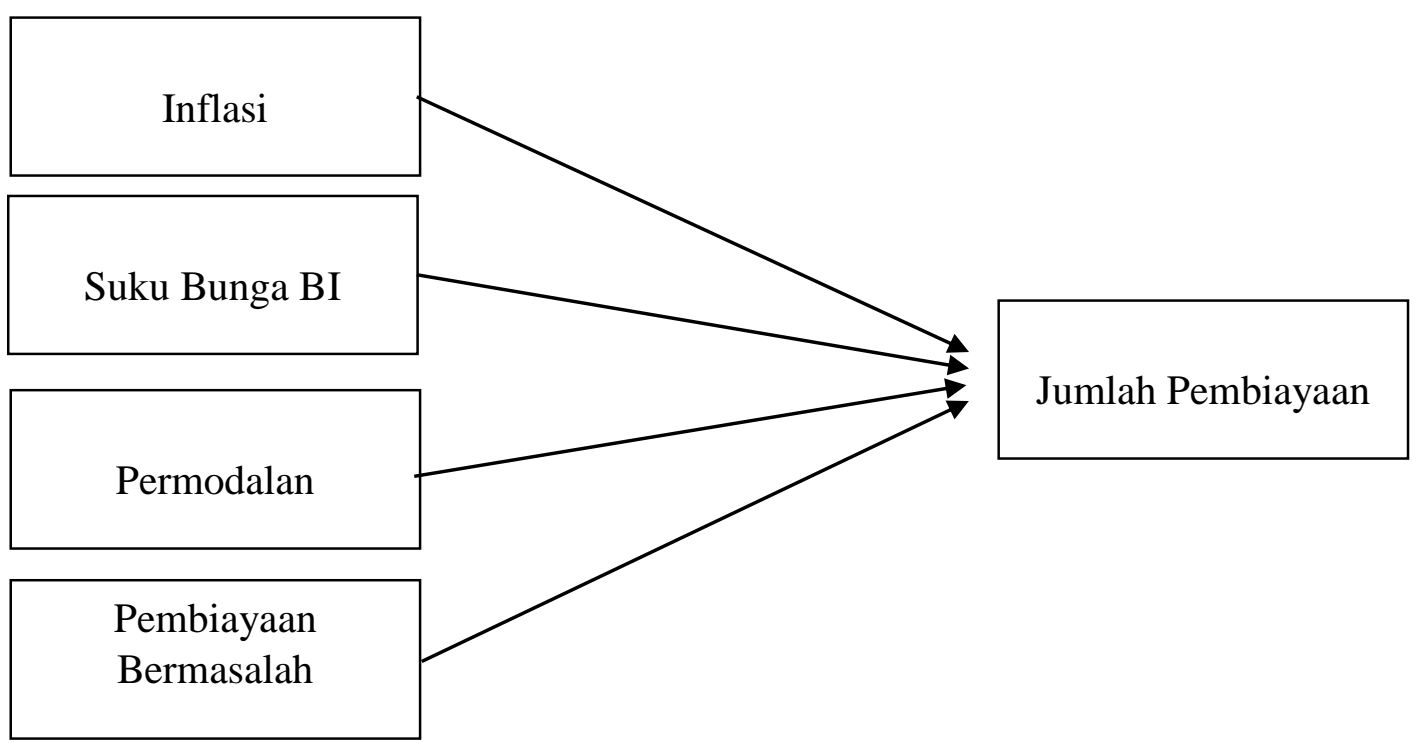

Berdasarkan penjelasan dan hasil penelitian terdahulu, maka hipotesis penelitian dapat ditulis ;

$\mathrm{H}_{1}$ : Inflasi Berpengaruh Terhadap Jumlah Pembiayaan

$\mathrm{H}_{2}$ : Suku Bunga Berpengaruh Terhadap Jumlah Pembiayaan

$\mathrm{H}_{3}$ : Permodalan Berpengaruh Terhadap Jumlah Pembiayaan

$\mathrm{H}_{4}$ : Pembiayaan Bermasalah Berpengaruh Terhadap Jumlah Pembiayaan

\section{METODE PENELITIAN}

\section{Pengukuran Varibel}

\section{Variabel Dependen (Y)}

Variabel Dependen adalah variabel terikat yang tidak bisa berdiri sendiri atau bisa dikatakan variabel yang masih memerlukan variabel lain yang dipengaruhi oleh variabel independen. Variabel dependen yang digunakan dalam penelitian ini adalah Jumlah Pembiayaan. Jumlah pembiayaan dalam penelitian ini dapat dilihat pada laporan keuangan tahunan atau bulanan pada perusahaan yang melakukan publikasi pada OJK atau website dari masing-masing bank dan diukur dengan desimal. Penyaluran pembiayaan dapat dinyatakan dalam rumus sebagai berikut:

Pembiayaan $=$ Ln (Jumlah pembiayaan yang diberikan) 


\section{Variabel Independen (X)}

Variabel Independen merupakan variabel bebas yang dapat memengaruhi variabel dependen. Variabel independen dalam penelitian ini adalah inflasi, suku bunga, permodalan, dan pembiayaan bermasalah. Berikut penjelasan dari tiap-tiap variabel independen:

1) Inflasi $\left(X_{1}\right)$

Inflasi adalah suatu kondisi dimana menggambarkan harga barang-barang komoditas atau jasa mengalami kenaikan secara terus menerus dan nilai mata uang mengalami penurunan. Inflasi dalam penelitian ini diukur dengan ratarata IHK yang mengukur harga rata-rata barang atau jasa yang dikonsumsi rumah tangga. Data inflasi juga dapat dilihat di website Bank Indonesia. Berdasarkan penelitian ini, data tersebut diambil dari periode 2016 sampai dengan 2018, kemudian data tersebut diolah menjadi rata-rata inflasi per tahun.

$$
I R_{X}=\frac{C P I_{X}-C P I_{X}-1}{C P I_{X}-1} \times 100
$$

2) Suku Bunga $\left(X_{2}\right)$

Suku bunga Bank Indonesia merupakan implementasi operasi moneter dalam merespon permasalahan ekonomi yang terjadi di Indonesia. Dengan kebijakannya ini, diharapkan dapat mengatasi permasalahan-permasalahan ekonomi yang sedang terjadi. Dalam penelitian ini, BI 7day Repo Rate diambil sebagai alat ukur dan data ini dapat diambil dari website Bank Indonesia yang berdasarkan periode penelitian yaitu dari tahun 2016 sampai 2018. Kemudian data yang didapat dirata-ratakan menjadi data BI 7day Repo Rate per tahun.

3) Permodalan $\left(X_{3}\right)$

Modal merupakan sejumlah uang yang ditanamkan oleh pemiliknya sebagai dasar untuk memulai operasional usahanya maupun untuk melakukan ekspansi usahanya yang dapat menghasilkan keuntungan guna untuk menambah aset. Semakin banyak modal yang dimiliki oleh suatu bank, maka bank akan semakin mampu mengatasi risiko kerugian yang akan terjadi. Dalam penelitian ini menggunakan rasio CAR untuk menghitung modal yang diambil dari periode 2016 sampai 2018 dan dihitung dengan rumus:

4) Pembiayaan Bermasalah $\left(X_{4}\right)$

$$
C A R=\frac{M_{\text {tier } 1}+M_{\text {tier } 2}+M_{\text {tier } 3}-\text { Penyertaan }}{A T M R} \times 100 \%
$$

Pembiayaan bermasalah merupakan terdapat suatu penyimpangan dalam hal kewajiban yang menyebabkan keterlambatan dalam pembayaran. NPF merupakan rasio yang digunakan dalam konsep syariah yang artinya adalah 
rasio yang menghitung pembiayaan bermasalah yang termasuk dalam klasifikasi macet, bermasalah, dan kurang lancar. Dalam penelitian ini, rasio NPF dijadikan alat ukur dan diambil pada periode 2016 sampai 2018 dan dapat dihitung dengan rumus:

$$
N P F=\frac{N P F \text { atau Pembiayaan UMKM }}{\text { Total Pembiayaan }} \times 100 \%
$$

Dalam penelitian ini, penentuan populasi dan sampel diperlukan untuk mempersempit kompleksitas dan untuk mempersingkat waktu, biaya dan tenaga serta mendapatkan sampel seusai dengan syarat yang serupa dengan populasi. Populasi yang dijadikan sebagai objek penelitian ini adalah Bank Umum Syariah yang terdaftar pada Otoritas Jasa Keuangan (OJK) selama periode 2016 sampai 2018.

\section{Populasi dan Sampel}

Teknik penentuan sampel dalam penelitian ini menggunakan metode non probability sampling sebagai pemilihan sampel berdasarkan syarat atau ketentuan tertentu yaitu sampel jenuh.

\section{Teknik Pengumpulan Data}

Jenis data yang digunakan dalam penelitian ini adalah data sekunder. Data sekunder yang dibutuhkan dalam penelitian ini adalah laporan keuangan perusahaan sektor perbankan dari Bank Umum Syariah yang terdaftar di OJK periode tahun 20162018. Sumber data yang digunakan dalam penelitian ini diperoleh dari laporan keuangan perusahaan sektor perbankan syariah yang dapat diakses pada website masing-masing bank yang dipublikasi di Bank Umum Syariah yang terdaftar di OJK dan website Bank Indonesia.

Dalam penelitian ini, uji data yang digunakan dalam penelitan ini adalah analisis deskriptif, regresi data panel yang melalui beberapa tahap yaitu Analisis Statistik Deskriptif, Uji Chow (F), Uji Haussman, dan Uji Langrage Multiplier dimana pendekatannya menggunakan metode fixed effect, random effect dan common effect.

Dalam penelitian ini untuk menguji hipotesisnya menyelesaikan keputusan hipotesis yang telah dibuat dapat menggunakan metode sebagai berikut:

\section{Uji Parsial (Uji t)}

Menurut Ghozali dan Ratmono (2017, hlm. 57) "menyatakan bahwa menyatakan bahwa uji t pada dasarnya menunjukkan seberapa jauh pengaruh satu variabel independen secara individual dalam menerangkan variasi variabel dependen dengan menganggap variabel independen lainnya konstan. Dalam uji ini pengambilan keputusan didasarkan pada tingkat signifikan sebesar $5 \%$ atau $0.05 . "$ 


\section{Uji Koefisien Determinasi (Uji $\mathbf{R}^{\mathbf{2}}$ )}

Menurut Ghozali dan Ratmono (2017, hlm. 55) bahwa "koefisien determinasi pada intinya mengukur seberapa jauh kemampuan model dalam menerangkan variasi variabel independen. Nilai koefisien determinasi adalah antara nol dan satu."

\section{HASIL DAN PEMBAHASAN}

\section{Analisis Statistik Deskriptif}

Analisis statistik deskriptif membantu mendeskripsikan data yang dimiliki dari nilai rata-rata, standar deviasi, maksimum, minimum, dari masing-masing variabel dalam penelitian. Variabel dependen $(\mathrm{Y})$ yang digunakan dalam penelitian ini adalah jumlah pembiayaan dan variabel independen $(X)$ yang digunakan dalam penelitian ini adalah inflasi, suku bunga $\mathrm{BI}$, permodalan dan pembiayaan bermasalah.

Tabel 1. Hasil Analisis Statistik Deskriptif

\begin{tabular}{lccccc}
\hline \hline & Pembiayaan & Inflasi & Suku_Bunga_Bi & Permodalan & Pembiayaan_Bermasalah \\
\hline \hline Mean & 8.825167 & 0.035133 & 0.049100 & 0.268183 & 0.052186 \\
Median & 8.621950 & 0.035300 & 0.050600 & 0.204150 & 0.032900 \\
Maximum & 11.12360 & 0.038100 & 0.051100 & 1.630700 & 0.439900 \\
Minimum & 4.280000 & 0.032000 & 0.045600 & 0.115100 & 0.000000 \\
Std. Dev. & 1.344959 & 0.002523 & 0.002513 & 0.245581 & 0.075400 \\
Observations & 42 & 42 & 42 & 42 & 42 \\
Sumber: Output E-Views & & & &
\end{tabular}

Variabel Pembiayaan

Rata-rata nilai variabel pembiayaan dari 14 perusahaan sektor perbankan syariah kelompok bank umum syariah selama 3 tahun adalah sebesar 8.825167 . Perusahaan sektor perbankan syariah ini memiliki nilai tertinggi dari variabel pembiayaan yang diperoleh Bank Syariah Mandiri yaitu sebesar 11.12360. Kemudian untuk bank dengan jumlah pembiayaan terendah adalah Maybank Syariah Indonesia pada tahun 2018 yaitu sebesar 4.280000. Dengan nilai standar deviasi sebesar 1.403868 dimana nilai tersebut lebih kecil dibandingkan dengan nilai rata-rata, dapat diartikan bahwa nilai maksimum dan nilai minimum tidak memiliki perbedaan yang signifikan. (terdistribusi dengan baik).

Variabel Inflasi

Rata-rata nilai variabel inflasi yang terjadi selama periode 2016 sampai 2018 adalah 0.035133 atau $3.51 \%$ atau masih dalam kategori inflasi ringan. Pada tahun 2017 terjadi inflasi tertinggi selama 3 periode yaitu 0.038100 atau $3.81 \%$ dan tingkat inflasi terendah terjadi pada tahun 2018 sebesar 0.032000 atau 3.20\%. Serta standar 
deviasi pada inflasi sebesar 0.002523 atau dapat dikatakan lebih kecil dari rata-rata maka nilai maksimum dan nilai minimum tidak memiliki perbedaan yang signifikan.

Variabel Suku Bunga BI

Rata-rata nilai variabel suku bunga BI atau BI 7day Repo Rate selama periode 2016 sampai 2018 adalah sebesar 0.049100 atau 4.91\%. Suku bunga BI tertinggi berada pada tahun 2016 sebesar 0.051100 atau 5.11\% dan suku bunga terendah berada pada tahun 2017 yaitu sebesar 0.045600 atau 4.56\%. Serta standar deviasi pada suku bunga BI sebesar 25.1337 atau dapat dikatakan lebih kecil dari rata-rata maka nilai maksimum dan nilai minimum tidak memiliki perbedaan yang signifikan. Variabel Permodalan

Rata-rata nilai variabel permodalan selama periode 2016 sampai 2018 adalah sebesar 0.268183 . Nilai tertinggi dari variabel permodalan sebesar 1.630700 yang terjadi pada perusahaan Maybank Syariah Indonesia, dan nilai terendah dari variabel permodalan sebesar 0.115100 yang diperoleh Bank Panin Dubai Syariah. Serta nilai standar deviasi pada variabel permodalan ini sebesar 0.245581 atau dapat dikatakan nilai tersebut masih lebih rendah dari rata-rata maka nilai maksimum dan nilai minimum tidak memiliki perbedaan yang signifikan.

Variabel Pembiayaan Bermasalah

Rata-rata nilai variabel pembiayaan bermasalah dari 14 perusahaan sektor perbankan syariah kelompok bank umum syariah selama 3 tahun adalah sebesar 0.052186 . Perusahaan sektor perbankan syariah ini memiliki nilai tertinggi dari variabel pembiayaan bermasalah yang diperoleh Maybank Syariah Indonesia yaitu sebesar 0.439900. Kemudian untuk bank dengan jumlah pembiayaan bermasalah terendah adalah Bank Victoria Syariah pada tahun 2017 yaitu sebesar 0.000000 . Dengan nilai standar deviasi sebesar 0.075400 dimana nilai tersebut lebih besar dibandingkan dengan nilai rata-rata, dapat diartikan bahwa nilai maksimum dan nilai minimum memiliki perbedaan yang signifikan.

2. Analisis Regresi Data Panel

a. Hasil Uji Chow

Tabel 2. Hasil Uji Chow

Redundant Fixed Effects Tests

Equation: Untitled

Test cross-section fixed effects

\begin{tabular}{lrrr}
\hline \hline Effects Test & Statistic & d.f. & Prob. \\
\hline \hline Cross-section F & 148.316483 & $(13,24)$ & 0.0000 \\
Cross-section Chi-square & 184.741808 & 13 & 0.0000 \\
\hline \hline
\end{tabular}

Sumber: Output E-Views 
Berdasarkan tabel 2 di atas, dapat diketahui nilai probabilitas Cross Section ChiSquare dalam penelitian ini sebesar 0.0000 atau $<0.05$ maka $\mathrm{H}_{0}$ ditolak dan $\mathrm{H}_{1}$ Tabel 11. Hasil Uji

diterima. Sehingga model yang terbaik berdasarkan uji Chow antara model common effect dengan model fixed effect adalah model fixed effect.

b. Hasil Uji Haussman

Table 2. Hasil Uji Haussman

Correlated Random Effects - Hausman Test

Equation: Untitled

Test cross-section random effects

\begin{tabular}{lrrr}
\hline \hline Test Summary & $\begin{array}{c}\text { Chi-Sq. } \\
\text { Statistic }\end{array}$ & Chi-Sq. d.f. & Prob. \\
\hline \hline Cross-section random & 0.000000 & 4 & 1.0000 \\
\hline \hline
\end{tabular}

* Cross-section test variance is invalid. Hausman statistic set to zero.

Sumber: Output E-Views

Pada tabel 3, dapat diketahui bahwa nilai perhitungan statistik uji Haussman adalah sebesar 0.000 dan nilai kritis Chi Square dengan df sebesar 4 serta probabilitas Cross-section random dalam penelitian ini sebesar 1.0000 dalam arti lebih dari 0.05 . Maka $\mathrm{H}_{0}$ diterima dan $\mathrm{H}_{1}$ ditolak, sehingga model yang terbaik dalam penelitian ini adalah model random effect dibandingkan dengan model fixed effect. Namun terdapat keterangan bahwa uji Haussman yang dilakukan tidak valid, hal tersebut dikarenakan data penelitian belum memenuhi syarat adanya model random effect maka $e$ views akan menolak uji Haussman. Sehingga dapat disimpulkan model terbaik yang digunakan dalam penelitian ini adalah model fixed effect dan tidak melanjutkan ke uji selanjutnya yaitu uji Langrage Multiplier (LM). 
a. Hasil Uji Fixed Effect Model

Tabel 3. Hasil Model Fixed Effect

\begin{tabular}{lrrrr}
\hline \multicolumn{1}{c}{ Variable } & Coefficient & Std. Error & t-Statistic & Prob. \\
\hline \hline C & 11.68038 & 1.161078 & 10.05994 & 0.0000 \\
Inflasi & -29.65695 & 14.61874 & -2.028695 & 0.0537 \\
Suku_Bunga_BI & -25.79063 & 14.25965 & -1.808644 & 0.0831 \\
Permodalan & -2.155066 & 0.205714 & -10.47602 & 0.0000 \\
Pembiayaan_Bermasalah & 0.594170 & 0.433690 & 1.370032 & 0.1834 \\
\hline \hline
\end{tabular}

Sumber: Output E-Views

Dari persamaan regresi di bawah dapat diuraikan sebagai berikut: Dapat dilihat bahwa hasil uji regresi pada nilai konstanta adalah sebesar 11.68038 , berarti jika nilai variabel inflasi, suku bunga BI, permodalan, dan pembiayaan bermasalah dianggap konstan atau sama dengan 0 (nol), maka nilai dari pembiayaan sebesar 11.68038

Nilai koefisien regresi untuk inflasi sebesar -29.65695 artinya pada perubahan satu satuan pada inflasi maka pembiayaan akan mengalami penurunan sebesar 29.65695 dengan asumsi variabel lain adalah tetap. Koefisien regresi bernilai negatif berarti variabel inflasi memiliki hubungan yang negatif.

Nilai koefisien regresi untuk suku bunga $\mathrm{BI}$ yang diukur dengan $\mathrm{BI} 7$ day $R R$ sebesar - 25.79063 artinya pada perubahan satu satuan pada suku bunga BI maka pembiayaan akan mengalami penurunan sebesar 25.79063 dengan asumsi variabel lain adalah tetap. Koefisien regresi bernilai negatif berarti variabel suku bunga BI memiliki hubungan yang negatif.

Nilai koefisien regresi untuk permodalan yang diukur dengan CAR sebesar - 2.155066 artinya pada perubahan satu satuan pada permodalan maka pembiayaan akan mengalami penurunan sebesar 2.155066 dengan asumsi variabel lain adalah tetap. Koefisien regresi bernilai negatif berarti variabel permodalan memiliki hubungan yang negatif.

Nilai koefisien regresi untuk pembiayaan bermasalah yang diukur dengan NPF sebesar 0.594170 artinya pada perubahan satu satuan pada pembiayaan bermasalah maka pembiayaan akan mengalami kenaikan sebesar 0.594170 dengan asumsi variabel lain adalah tetap. Koefisien regresi bernilai positif berarti variabel pembiayaan bermasalah memiliki hubungan yang positif. 


\section{Uji Hipotesis}

a. Hasil Uji t

Berdasarkan tabel 5 di bawah, hasil output data statistik dengan menggunakan E-views 10, maka dapat dilihat terdapat pengaruh antara variabel independen terhadap variabel dependen secara parsialmatau uji t adalah sebagai berikut:

Table 4. Hasil Uji t

\begin{tabular}{lrrrr}
\multicolumn{1}{c}{ Variable } & Coefficient & Std. Error & t-Statistic & Prob. \\
\hline \hline C & 11.68038 & 1.161078 & 10.05994 & 0.0000 \\
Inflasi & -29.65695 & 14.61874 & -2.028695 & 0.0537 \\
Suku_Bunga_Bi & -25.79063 & 14.25965 & -1.808644 & 0.0831 \\
Permodalan & -2.155066 & 0.205714 & -10.47602 & 0.0000 \\
Pembiayaan_Bermasalah & 0.594170 & 0.433690 & 1.370032 & 0.1834 \\
\hline \hline
\end{tabular}

Effects Specification

Cross-section fixed (dummy variables)

\begin{tabular}{ll}
\hline \hline R-squared & 0.964145 \\
Adjusted R-squared & 0.969998
\end{tabular}

Pengaruh inflasi terhadap Pembiayaan

Sumber: Output E-Views

Berdasarkan hasil analisis pada tabel 5, diketahui bahwa variabel inflasi yang diukur dengan Indeks Harga Konsumen (IHK) menunjukkan nilai thitung lebih kecil dari $t_{\text {tabel }}$ yaitu $-2.028695<2.02619$ dan nilai signifikansi lebih besar $0.0537>0.05$ dengan nilai koefisien sebesar -29.65695 maka $\mathrm{H}_{0}$ diterima dan $\mathrm{H}_{a}$ ditolak, sehingga dapat dikatakan bahwa inflasi tidak berpengaruh terhadap pembiayaan.

Pengaruh Suku Bunga BI terhadap Pembiayaan

Berdasarkan hasil analisis pada tabel 5 , diketahui bahwa variabel suku bunga $\mathrm{BI}$ yang diukur dengan BI 7day RR menunjukkan nilai thitung lebih kecil dari tabel yaitu $1.808644<2.02619$ dan nilai signifikansi lebih besar $0.0831>0.05$ dengan nilai koefisien sebesar -25.79063 maka $H_{0}$ diterima dan $H_{a}$ ditolak, sehingga dapat dikatakan bahwa suku bunga BI tidak berpengaruh terhadap pembiayaan.

Pengaruh Permodalan terhadap Pembiayaan

Berdasarkan hasil analisis pada tabel 5, diketahui bahwa variabel permodalan yang diukur dengan CAR menunjukkan nilai thitung lebih kecil dari tabel yaitu -10.47602 $<2.02619$ dan nilai signifikansi lebih kecil $0.000<0.05$ dengan nilai koefisien sebesar -2.155066 maka $\mathrm{H}_{0}$ ditolak dan $\mathrm{H}_{\mathrm{a}}$ diterima, sehingga dapat dikatakan bahwa permodalan berpengaruh terhadap pembiayaan. 
Pengaruh Pembiayaan Bermasalah terhadap Pembiayaan

Berdasarkan hasil analisis pada tabel 5, diketahui bahwa variabel pembiayaan bermasalah yang diukur dengan NPF menunjukkan nilai $t_{\text {hitung }}$ lebih kecil dari $t_{\text {tabel }}$ yaitu $1.370032<2.02619$ dan nilai signifikansi lebih besar $0.1834>0.05$ dengan nilai koefisien sebesar 0.594170 maka HO diterima dan Ha ditolak, sehingga dapat dikatakan bahwa pembiayaan bermasalah tidak berpengaruh terhadap pembiayaan.

b. Hasil Uji Koefisien Determinasi $\left(R^{2}\right)$

Dalam penelitian ini, uji koefisien determinasi dilakukan untuk mengukur seberapa besar proposi variabel dependen (pembiayaan) yang dijelaskan oleh semua variabel independen (Inflasi, Suku Bunga BI, Permodalan, Pembiayaan Bermasalah). Uji koefisien determinasi adalah berada diantara nol dengan satu. Semakin besar nilai koefisien determinasi maka semakin besar pula variabel independennya dalam menjelaskan variansi dari variabel dependennya.

Berdasarkan tabel 5, memperlihatkan hasil koefisien determinasi yang digunakan adalah adjusted $R$-squared sebesar 0.969998. Hal ini dapat menunjukkan bahwa variabel independen yaitu Inflasi, Suku Bunga BI, Permodalan dan Pembiayaan Bermasalah dapat menerangkan atau menjelaskan $96.9998 \%$ terhadap total varians variabel dependen yaitu pembiayaan dan sisanya sebesar 3.0002\% (100\%-96.9998\%) dijelaskan oleh variabel lain selain yang terdapat dalam penelitian ini.

\section{Pembahasan}

Berdasarkan hasil pengujian regresi data panel, memperoleh hasil bahwa variabel inflasi tidak berpengaruh terhadap pembiayaan, maka dapat dikatakan bahwa Hipotesis pertama atau $\mathrm{H}_{1}$ ditolak. Hal ini dapat menunjukkan bahwa selama tahun penelitian inflasi tidak berpengaruh terhadap pembiayaan.

Dari hasil penelitian ini inflasi tidak berpengaruh terhadap penyaluran pembiayaan karena bank umum syariah tidak menggunakan sistem bunga. Sehingga tingkat bagi hasil dari produk bank syariah tidak harus beradaptasi diri dengan inflasi seperti layaknya suku bunga BI. Hal ini disebabkan karena inflasi pada tahun 2016 sampai 2018 masih dalam kategori inflasi ringan sehingga pemerintah tidak perlu mengeluarkan kebijakan moneter dan pemerintah masih dapat mengatasi inflasi yang terjadi pada saat itu. Hal ini juga dapat dilihat rata-rata inflasi 2016-2018 masih rendah selama 3 periode, sehingga bank umum syariah masih dapat menjalankan tugasnya sebagai fungsi intermediasi dengan baik. Hasil penelitian ini sesuai dengan penelitian Masudah (2017), Dahlan (2015).

Berdasarkan hasil pengujian regresi data panel, memperoleh hasil bahwa variabel Suku Bunga BI tidak berpengaruh terhadap pembiayaan, maka dapat 
dikatakan bahwa Hipotesis kedua atau $\mathrm{H}_{2}$ ditolak. Hal ini dapat menunjukkan bahwa selama tahun penelitian suku bunga BI tidak berpengaruh terhadap pembiayaan.

Dari hasil penelitian ini Suku Bunga BI tidak berpengaruh terhadap penyaluran pembiayaan karena bank umum syariah tidak terlalu memperhatikan kondisi makroekonomi yaitu suku bunga konvensional. Bank syariah menyalurkan pembiayaan dengan berbasis profit sharing dan ini menunjukkan bahwa perbankan syariah bebas dari unsur bunga. Dalam menetapkan marjin keuntungan bank syariah pada umumnya berpacu pada rata-rata pinjaman yang ada pada bank konvensional. Hal ini juga didukung oleh prinsip bank syariah yaitu tidak mengedepankan profit yang didapat, tetapi yang menjadi utamanya adalah bank syariah mampu memenuhi kebutuhan sesuai dengan prinsip islam. Hasil penelitian ini sesuai dengan penelitian Jayanti (2016), dan Kiswanto (2014).

Berdasarkan hasil pengujian regresi data panel, memperoleh hasil bahwa variabel Permodalan berpengaruh terhadap pembiayaan, maka dapat dikatakan bahwa Hipotesis ketiga atau $\mathrm{H}_{3}$ diterima. Hal ini dapat menunjukkan bahwa selama tahun penelitian permodalan dengan satuan hitung CAR, berpengaruh terhadap pembiayaan. Berdasarkan hal tersebut, apabila permodalan mengalami penurunan maka hal akan menurunkan jumlah pembiayaan yang disalurkan, dan sebaliknya.

Dengan modal yang memadai, maka akan membentuk kepercayaan diri dari masyarakat maupun bank itu sendiri sehingga dapat memengaruhi keputusan masyarakat atau nasabah dalam melakukan pembiayaan. Karena salah satu sumber yang dapat digunakan dalam melakukan pembiayaan adalah modal sendiri atau dana pihak pertama, sehingga semakin besar sumber dana yang dimiliki oleh suatu bank maka bank dapat memberikan pembiayaan dalam batas maksimum yang besar juga. Semakin meningkatnya jumlah permodalan pada suatu bank, maka akan semakin baik pula kinerja perbankan dalam menunjang aktivanya yang mengandung risiko. Hasil penelitian ini sesuai dengan penelitian Ali dan Miftahurrohman (2016), dan Ambarwati dan Kiwanto (2014).

Berdasarkan hasil pengujian regresi data panel, memperoleh hasil bahwa variabel Permodalan berpengaruh terhadap pembiayaan, maka dapat dikatakan bahwa Hipotesis keempat atau $\mathrm{H}_{4}$ ditolak. Hal ini dapat menunjukkan bahwa selama tahun penelitian pembiayaan bermasalah dengan satuan hitung NPF, tidak berpengaruh terhadap pembiayaan. Berdasarkan hal tersebut, apabila pembiayaan mengalami penurunan maka belum tentu menurunkan jumlah pembiayaan yang disalurkan, dan sebaliknya.

Dalam hasil penelitian ini, pembiayaan bermasalah tidak berpengaruh terhadap penyaluran pembiayaan karena hal ini dapat menunjukkan bahwa sebagaimana bank dalam menjalankan tugasnya dengan menyalurkan pinjaman akan tetap berjalan walaupun tingkat pembiayaan bermasalah pada suatu bank mengalami kenaikan 
atau penurunan. Hal ini dapat dilihat bahwa pembiayaan bermasalah selama periode penelitian. Berdasarkan surat edaran Bank Indonesia No. 17/19/DPUM tentang pemberian kredit atau penyaluran pembiayaan oleh bank umum di Indonesia dengan angka 5.18\% bank tersebut tergolong bank sehat. Jika terjadi pembiayaan bermasalah yang termasuk klasifikasi tertentu, maka bank sudah memiliki alternatif untuk mengatasi hal tersebut sehingga penyaluran pembiayaan masih akan tetap berjalan. Dengan tingkat pembiayaan masalah ditekankan, maka akan diikuti menurunnya risiko yang akan diterima yang akan mempengaruhi kepercayaan nasabah atau masyarakat. Hasil penelitian ini sesuai dengan penelitian Masudah (2017), dan Ali dan Miftah (2016)

\section{SIMPULAN}

Berdasarkan hasil penelitian dan pengujian hipotesis melalui analisis regresi data panel, maka dapat ditarik kesimpulan bahwa hasil pengujian variabel Inflasi yang diukur dengan inflation rate menunjukkan hasil yang mengemukakan bahwa Inflasi tidak berpengaruh terhadap jumlah Pembiayaan pada sektor perbankan kelompok Bank Umum Syariah yang terdaftar di Otoritas Jasa Keuangan (OJK) periode tahun 2016 sampai dengan 2018. Dengan demikian, hipotesis penelitian ini tidak terbukti. Hasil pengujian variabel Suku Bunga BI yang diukur dengan BI 7day Repo Rate menunjukkan hasil yang mengemukakan bahwa Suku Bunga BI (BI 7day Repo Rate) tidak berpengaruh terhadap jumlah Pembiayaan pada sektor perbankan kelompok Bank Umum Syariah yang terdaftar di Otoritas Jasa Keuangan (OJK) periode tahun 2016 sampai dengan 2018. Dengan demikian, hipotesis penelitian ini tidak terbukti.

Hasil pengujian variabel Permodalan yang diukur dengan Capital Adequacy Ratio menunjukkan hasil yang mengemukakan bahwa Permodalan (CAR) berpengaruh terhadap jumlah Pembiayaan pada sektor perbankan kelompok Bank Umum Syariah yang terdaftar di Otoritas Jasa Keuangan (OJK) periode tahun 2016 sampai dengan 2018. Dengan demikian, hipotesis penelitian ini terbukti. Hasil pengujian variabel Pembiayaan Bermasalah yang diukur dengan Non Performing Financing menunjukkan hasil yang mengemukakan bahwa Pembiayaan Bermasalah (NPF) tidak berpengaruh terhadap jumlah Pembiayaan pada sektor perbankan kelompok Bank Umum Syariah yang terdaftar di Otoritas Jasa Keuangan (OJK) periode tahun 2016 sampai dengan 2018. Dengan demikian, hipotesis penelitian ini tidak terbukti. 


\section{DAFTAR PUSTAKA}

Akbar, Masithah, and R.R. Siti Munawaroh. 2014. Analisis Pengaruh Dana Pihak Ketiga, Tingkat Suku Bunga Kredit, Non Performance Loan (Npl), Dan Tingkat Inflasi Terhadap Penyaluran Kredit Bank Pemerintah Di Kalimantan Selatan. Jurnal Spread 4(April): 43-52.

Ali, Herni, and Miftahurrohman Miftahurrohman. 2016. Determinan Yang Mempengaruhi Pembiayaan Murabahah Pada Perbankan Syariah Di Indonesia. Esensi 6(1): 31-44.

Ambarwati, Wahyuli Wulandari, and Kiswanto. 2013. Faktor-Faktor yang Mempengaruhi Pembiayaan Berbasis Bagi Hasil (Profit And Loss Sharing 3(2): 437-46.

Annisa, Suci, and Dedi Fernanda. 2017. Pengaruh DPK, CAR, NPF Dan ROA Terhadap Pembiayaan Mudharabah Pada Bank Syariah Mandiri Periode 2011-2015. Jurnal Ekonomi \& Bisnis Dharma Andalas 19(2): 300-305.

Anthony, Robert N, and Vijay Govindarajan. 2005. Sistem Pengendalian Manajemen. Jakarta: Salemba Empat.

April. 2017. Pengaruh Dana Pihak Ketiga (Dpk), Capital Adequacy Ratio (Car), Non Performing Finance (Npf) Terhadap Pembiayaan 5(3): 1535-40.

Asiyah, Binti Nur. 2014. Manajemen Pembiayaan Bank Syariah. Yogyakarta: Teras.

Aziza, Ratu Vien Sylvia, and A D E Sofyan Mulazid. 2015. Analisis Pengaruh Dana Pihak Ketiga, Non Performing Financing, Capital Adequacy Ratio, Modal Sendiri Dan Marjin Keuntungan Terhadap Pembiayaan Murabahah. Jurnal Ekonomi dan Bisnis Islam (JEBI) 2: 1-15.

Azka, Widya Karunia, Hardiwinoto, and R Ery Wibowo. 2018. Analisis Faktor-Faktor Yang Mempengaruhi Pembiayaan Murabahah Pada Perbankan Syariah Di Indonesia. Economics Development Analysis Journal 1(4): 418-24.

Bakti, Nurimansyah Setivia. 2018. Analisis Dpk, Car, Roa Dan Npf Terhadap Pembiayaan Pada Perbankan Syariah. Jurnal Bisnis dan Manajemen 17(2): 15.

Boediono. 2018. Ekonomi Makro. Yogyakarta: BPFE Yogyakarta.

Budi Untung.H. 2000. Kredit Perbankan Indonesia. Yogyakarta: Andi.

Dahlan, Rahmat. 2015. Pengaruh Tingkat Bonus Sertifikat Bank Indonesia Syariah Dan Tingkat Inflasi Terhadap Pembiayaan Bank Syariah Di Indonesia. Etikonomi 13(2): 8-9.

Dendawijaya, Lukman. 2009. Manajemen Perbankan. Jakarta: Ghalia Indonesia.

Dyatama, Ayank Narita, and Imamudin Yuliadi. 2015. Determinan Jumlah Pembiayaan. Jurnal Ekonomi \& Studi Pembangunan 16(April): 73-83.

Fahmi, Irham. 2015. Manajemen Investasi Teori Dan Soal Jawab. Edisi 2. Jakarta: Salemba Empat.

Ghozali, Imam, and Dwi Ratmono. 2017. Analisis Multivariat Dan Ekonometrika Dengan Eviews 10. Semarang: Badan Penerbit Universitas Diponegoro.

Hanifah. 2016. Financing to Deposit Ratio. Jurnal Ekonomi Keuangan dan Bisnis Islam 7(1): 19-36.

Haryani, Iswi, and Serfianto. 2010. Bebas Jeratan Utang Piutang. Yogyakarta: Pustaka Yustisia.

Hasibuan, Abdul Nasser. 2015. ASIMETRI INFORMASI DALAM PERBANKAN SYARIAH 
Abdul Nasser Hasibuan, SE., M.Si Dosen Fakultas Ekonomi Dan Bisnis Islam IAIN Padangsidimpuan. 1 (1): 43-66.

Hidayat, Taufik. 2016. Analisis Faktor-Faktor Yang Mempengaruhi Kinerja Manajerial. Akuntabilitas 7(1): 706-17.

Indonesia, Ikatan Bankir. 2015. Mengelola Bisnis Pembiayaan Bank Syariah. Jakarta: PT Gramedia Pustaka Utama.

Jayanti, Sri Delasmi. 2016. Pengaruh Inflasi Dan BI Rate Terhadap Pembiayaan Usaha Mikro Kecil Dan Menengah (Studi Kasus Pada Bank Umum Syariah). I-Economics 2(2): 86-105.

Kasmir. Dasar-Dasar Perbankan. In 2014, Jakarta: PT. Raja Grafindo Persada.

Lin, Huey-Yeh, Nuraeni Hadiati Farhani, and Meihua Koo. 2016. The Impact of Macroeconomic Factors on Credit Risk in Conventional Banks and Islamic Banks: Evidence from Indonesia. International Journal of Financial Research 7(4).

Machfudz, Masyhuri, dan Nurhadi Sujoni, M. 2016. Teori Ekonomi Makro. Malang: UIN-Maliki Pres.

Maidalena. 2014. Analisis Faktor Non Performing Financing (NPF) Pada Industri Perbankan Syariah. Jurnal Ekonomi dan Bisnis Islam 1(1): 127-38.

Marlina, Lisa, and Mia Angelina Setiawan. 2019. Pengaruh Kurs, Inflasi, Dana Pihak Ketiga (Dpk), Pendapatan Bank, Capital Adequecy Ratio (Car), Dan Non Performing Financing (Npf) Terhadap Tingkat Pengguliran Dana Bank Umum Syariah Non Devisa Periode 2014-2018. Jurnal Eksplorasi Akuntansi 1(3): 147293.

Marshall, Robert, and Miranda. 2003. Kamus Populer Uang Dan Bank. Jakarta: Ladang pustaka dan Inti media.

Masudah. 2017. Penerapan PSAK NO. 102 Atas Transaksi Murabahah: Studi Pada Baitul Maal Wa Tamwil Di Depok, Jawa Barat. Ikonomika 2(1): 53-62.

Nahrawi, Amirah Ahmad. 2017. Pengaruh Capital Adequacy Ratio (CAR), Return On Assets (ROA) Dan Non Performing Financing (NPF) Terhadap Pembiayaan Murabahah BNI Syariah. Perisai : Islamic Banking and Finance Journal 1(2): 141.

Pandia, Frianto. 2012. Manajemen Dana Dan Kesehatan Bank. Cetakan Pe. Jakarta: Rineka Cipta.

Profitabilitas. 2015. Faktor-Faktor Penentu Profitabilitas Bank Syariah Di Indonesia. Management Analysis Journal 4(1): 39-49.

Ramadani, Fitri. 2018. Pengaruh Inflasi, Suku Bunga Dan Nilai Tukar Rupiah Terhadap Harga Ssaham Perusahaan Sektor Properti Dan Real Estate Yang Tercatat Di Bursa Efek Indonesia. Manajemen Bisnis 6(1): 72-82.

Ramadhan, Prasetyo. 2017. Determinan Pembiayaan Bermasalah Sektor Pertambangan Pada Perbankan Syariah. Akuntabilitas 10(2): 369-90.

Ridwan, Muhammad, and Mohammad Rizal. 2018. Perbankan Syariah. Malang: Empat Dua Media.

Riyadi, Selamet, and Rais Muhcamad Raffii. 2018. Pengaruh Dana Pihak Ketiga, Capital Adequacy Ratio, Bi Rate, Dan Financing To Deposit Ratio Terhadap Pembiayaan Murabahah Pada Bank Syariah Di Indonesia. Perbanas Rerview 3(2): 18.

Rohmadoni, Purnama, Bayu. 2016. Pengaruh Net Interest Margin Dan Inflasi 
Terhadap Penyaluran Kredit Di Indonesia Pada Bank Umum Di Indonesia. Jurnal Pendidikan Ekonomi (JUPE) 4(3).

Salma Fathiya Ma'arifa, Iwan Budiyono. 2015. Analisis Pengaruh Dana Pihak Ketiga, Sertifikat Bank Indonesia Syariah, Bi Rate, Dan Inflasi Terhadap Pembiayaan Murabahah Perbankan Syariah Di Indonesia Periode 2006-2014. 5(1).

Saputri. 2018. Determinan Pembiayaan UMKM Di Indonesia Tahun 2011-2015: Pendekatan Generalized Method Of Moment (GMM). Al-Amwal, Volume 10, No. 1 Tahun 2018 10(1).

Sugiyono. 2017. Metode Penelitian Kuantitatif, Kualitatif, Dan R\&D. Bandung: Alfabeta, CV.

Suryani dan Hendryadi. 2015. Metode Riset Kuantitatif Teori Dan Aplikasi Pada Penelitian Bidang Manajemen Dan Ekonomi Islam.

Susilo, Edi. 2017. Analisis Pembiayaan Dan Risiko Perbankan Syariah. Jilid 2. Jogja: Pustaka Pelajar(unisnupress).

Syaikh, Stain, Abdurrahman Siddik, and Bangka Belitung. 2017. Manajemen Permodalan Bank Syariah. Bisnis 5(2): 323-38.

Trisadini, Usanti. 2013. Transaksi Bank Syari'ah. Jakarta: PT Bumi Aksara.

Veratama, Yuhan. 2013. Pengaruh Kurs, Inflasi, Dpk, Swbi, Dan Pendapatan Bank Terhadap Tingkat Pengguliran Dana Bank Syariah. : 1-17.

Vijaya, Diota Prameswari, and M. Rudi Irwansyah. 2018. Pengaruh Modal Psikologis, Karakteristik Wirausaha, Modal Usaha Dan Startegi Pemasaran Terhadap Perkembangan Usaha Umkm Di Kecamatan Buleleng Tahun 2017. Ekuitas: Jurnal Pendidikan Ekonomi 5(1).

Waemustafa, Waeibrorheem, and Suriani Sukri. 2015. Bank Specific and Macroeconomics Dynamic Determinants of Credit Risk in Islamic Banks and Conventional Banks. International Journal of Economics and Financial Issues 5(2): 476-81.

Wardiantika, Lifstin, and Rohmawati Kusumaningtias. 2014. Pengaruh Dpk, Car, Npf, Dan Swbi Terhadap Pembiayaan Murabahah Pada Bank Umum Syariah Tahun 2008-2012. ifstin Jurnal IImu Manajemen (JIM) 2(4): 1550-61. http://jurnalmahasiswa.unesa.ac.id/index.php/jim/article/view/11151.

Wicaksono, Rianto Anugerah. 2015. Bank Konvensional Dan Tingkat Suku Bunga Bank Indonesia Terhadap Pembiayaan Bank Islam Berbasis Murabahah. Jurnal Aplikasi Manajemen 13(3): 494-501. 